\title{
Pembinaan Olahraga Renang bagi Siswa Berprestasi dalam cabang Olahraga Renang di SLB
}

\author{
Ragil Tri Wibowo, Sopingi \\ Universitas Negeri Malang \\ E-mail: ragil3wibowo@gmail.com. 081331010746
}

\begin{abstract}
Abstrak: Olahraga renang merupakan olahraga yang memiliki banyak manfaat bagi orang yang melakukannya tidak kecuali anak berkebutuhan khusus. Tujuan dalam penelitian ini adalah untuk mendeskripsikan (1) program pembinaan olahraga renang bagi siswa berprestasi, (2) pelaksanaan pembinaan olahraga renang bagi siswa berprestasi, (3) hambatan pembinaan olahraga renang bagi siswa berprestasi, dan (4) upaya mengatasi hambatan pembinaan olahraga renang bagi siswa berprestasi. Metode dalam penelitian ini adalah metode penelitian kualitatif dengan menggunakan pendekatan studi kasus. Hasil dari penelitian ini menunjukan bahwa (1) program pembinaan olahraga renang yaitu pihak sekolah melakukan kerjasama dengan orangtua untuk mendaftarkan ke klub renang, kemudian klub renang memberikan program latihan bagi siswa, (2) pelaksanaan pembinaan olahraga renang dibagi menjadi dua, yaitu di sekolah dan di klub renang, (3) hambatan pelaksanaan pembinaan olahraga renang, tidak adanya sarana di sekolah dan mood siswa; (4) upaya mengatasi hambatan pembinaan olahraga renang adalah kerjasama dengan orangtua dan lebih mengenali karakteristik siswa.
\end{abstract}

Kata kunci: pembinaan olahraga renang, siswa berprestasi, SLB

\begin{abstract}
Swimming is a sport that has many benefits for the people who do it, no exception for children with special need. The aims of this research are to describe: (1) program swimming training for students achievement in the swimming sport (2) the implementation of swimming training for students achievement in the swimming sport, (3) the barriers of swimming training for students achievement in the swimming sport, and (4) some efforts to overcome the barriers of swimming training for students achievement in the swimming sport. This research used qualitative method by using case study approach. The results of this researcher showed that (1) the programs of swimming training were the school did collaboration with parents to register the students to the Club pool, then the club provides training programs for the students, (2) the implementation of swimming training were divided into two, in schools and in the Club pool, (3) barriers in implementation of swimming training were no facilitiy in school and mood of students; (4) some efforts to overcame some barriers on swimming training were collaboration among parents and recognize more deeply the characteristics of students
\end{abstract}

Keywords: swimming training, students achievement, SLB

Anak berkebutuhan khusus adalah anak yang memiliki karakteristik khusus yang berbeda dengan anak pada umumnya serta mengalami hambatan pada fisik, mental, dan emosional sehingga membutuhkan penanganan khusus. Menurut Efendi (2008) mengkategorikan anak berkebutuhan khusus yang memiliki kelainan dalam aspek fisik meliputi kelainan penglihatan (tunanetra), kelainan kemampuan bicara (tunawicara), kelainan fungsi anggota tubuh (tunadaksa), dan kelainan pendengaran (tunarungu). Tunarungu adalah seseorang yang mengalami hambatan atau gangguan dalam indera pendengarannya. Tinggi rendahnya gradasi kehilangan pendengaran pada tunarungu dapat berpengaruh dalam kemampuannya menyimak suara langsung maupun latar belakang.

Selanjutnya, anak yang memiliki kelainan dalam aspek mental meliputi anak yang memiliki kemampuan mental lebih (supernormal) yang dikenal sebagai anak berbakat atau anak unggul, dan anak yang memiliki kemampuan mental sangat rendah (subnormal) yang dikenal sebagai anak tunagrahita. Pada masa awal perkembangannya hampir tidak ada perbedaan antara tunagrahita dengan anak normal, akan tetapi semakin lama perbedaan pola perkembangan antara tunagrahita dengan anak normal akan terlihat semakin jelas. Menurut Edgar Doll dalam (Efendi, 2008) seorang dikatakan tunagrahita jika: (1) secara sosial tidak cakap, (2) secara mental di bawah normal, (3) kecerdasannya terhambat sejak lahir atau pada usia muda, dan (4) kematangannya terhambat. Meskipun begitu mereka masih dapat dikembangkan melalui peningkatan prestasi yang disesuaikan dengan bakat dan minat. Bakat dan minat anak berkebutuhan khusus sangat beragam jenisnya. Salah satunya yaitu bakat dalam bidang olahraga. Olahraga merupakan suatu kegiatan yang melibatkan seluruh fungsi tubuh. Terdapat berbagai jenis olahraga yang dapat dilakukan oleh setiap orang. Salah satu olahraga yang cukup populer dikalangan masyarakat adalah olahraga renang. Hal tersebut dikarenakan renang merupakan olahraga yang memiliki banyak manfaat bagi pelakunya. Menurut Siregar (2014) renang bukan hanya salah satu olahraga yang memiliki banyak manfaat tetapi sangat bermanfaat juga bagi anak berkebutuhan khusus, 
sebagai contohnya yaitu dapat memberikan bantuan terapi pada kekuatan otot, meningkatkan relaksasi otot, dan membangun kekuatan otot karena renang membutuhkan gerakan hamper semua otot dalam tubuh sehingga dapat membantu anak berkebutuhan khusus mengembangkan kordinasi otot. Selain itu olahraga renang juga dapat menciptakan interaksi sosial yang baik sehingga mampu beradaptasi dan menyesuaikan diri serta dapat mengembangkan kepercayaan diri dan kemandiriannya. Dalam pembinaan renang sangat dibutuhkan kegiatan pengenalan air kepada siswa yang belum pernah sama sekali belajar renang, karena kemungkinan siswa ada yang masih merasa takut untuk masuk ke kolam. Menurut Sismadiyanto dan Susanto (2008) pengenalan air adalah suatu bentuk latihan dasar sebelum siswa diajarkan masing-masing gaya renang.

Selanjutnya penelitian Utomo (2016) menyimpulkan pembinaan olahraga adaptif secara proposional akan membawa calon-calon atlet paralympic bisa berkiprah di tingkat nasional, ASEAN, benua Asia bahkan sampai ke jenjang Paralympic Games tingkat dunia. Jadi berdasarkan penelitian terdahulu dapat disimpulkan pelaksanaan pembinaan kegiatan non akademik yang sesuai dengan bakat dan minat siswa akan menghasilkan sebuah prestasi. Untuk mencapai prestasi yang diingkan, sekolah juga harus berupaya memfasilitasi dan memberi akomodasi sesuai dengan kebutuhan siswa. Program bina gerak terdiri dari tujuan program bina gerak sebagai acuan keberhasilan program, materi program bina gerak, prosedur kegiatan program bina gerak, dan evaluasi program bina gerak (Pradipta, 2017). Sekolah juga harus cepat tanggap dalam mengatasi masalah-masalah yang dapat menghambat pelaksanaan pembinaan. SMPLB Negeri Malang merupakan salah satu sekolah yang berprestasi di kota Malang. Prestasi yang didapatkan SMPLB Negeri Malang lebih dominan dalam bidang non akademik. Prestasi non akademik ini meliputi olahraga dan keterampilan. Salah satu prestasi non akademik yang dicapai sampai tingkat nasional dalam bidang olahraga adalah olahraga renang. EC berhasil mendapatkan juara I lomba renang kategori tunarungu pada paralyimpic games tingkat kota di Malang, selanjutnya EC mewakili kota Malang di tingkat provinsi dan berhasil mendapatkan juara 3 lomba renang kategori tunarungu pada paralympic games tingkat provinsi di Surabaya. UK juga mendapatkan juara I lomba renang kategori tunagrahita pada paralympic games tingkat kota di Malang serta juara 2 lomba renang kategori tunagrahita pada paralympic games tingkat provinsi di Surabaya.

\section{METODE}

Metode yang akan digunakan dalam penelitian ini adalah metode penelitian kualitatif dengan jenis penelitian studi kasus. Penelitian kualitatif tidak hanya berdasarkan variabel penelitian tetapi seluruh situasi sosial yang diteliti, meliputi aspek tempat (place), pelaku (actor), dan aktivitas (activity) yang berinteraksi secara sinergis. Kehadiran peneliti merupakan instrumen kunci dalam penelitian kualitatif. Peneliti memiliki peran penting dalam merencanakan, melaksanakan, sampai mengevaluasi penelitian, mulai dari peneliti datang ke lapangan menggali data dan informasi, menganalisis sampai menyusun laporan maka kehadiran peneliti di lapangan mutlak diperlukan untuk penelitian ini.

Pengumpulan data dilakukan pada natural setting (kondisi alamiah), sumber data primer, dan teknik pengumpulan data lebih banyak pada observasi berperan serta (participan observation), wawancara mendalam (in depth interview) dan dokumentasi (Sugiyono, 2008). Dalam penelitian ini peneliti menggunakan teknik analisis data yang mengacu pada pendapat Miles dan Huberman (dalam Sugiyono 2008), terdapat tiga langkah yang digunakan dalam proses analisis data, antara lain (1) reduksi data, (2) penyajian data, dan (3) mengambil keputusan. Teknik pengecekan keabsahan data yang digunakan adalah teknik triangulasi. Peneliti menggunakan triangulasi sumber dan triangulasi teknik.

\section{HASIL DAN PEMBAHASAN}

\section{Hasil}

Program pembinaan olahraga renang dibagi menjadi 3 tahap, dapat dilihat pada gambar 1

\section{Gambar 1. Program Pembinaan Olahraga Renang}

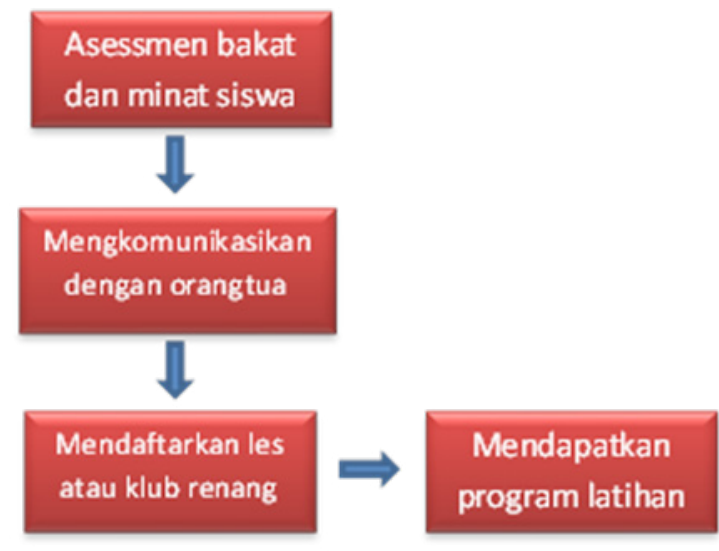

Tahap awal yang dilakukan sekolah dalam mengembangkan potensi bakat dan minat siswa adalah melakukan asessmen. Jika asessmen telah dilakukan selanjutnya pihak sekolah mengkomunikasikan hal tersebut kepada orangtua siswa. Sekolah melakukan kerjasama dengan orangtua terkait pembinaan olahraga renang yaitu dengan mendaftarkan siswa untuk ikut 
les atau klub renang. Setelah mengikuti klub renang siswa akan memperoleh program-program latihan renang dari klub renang tersebut. Hal ini bertujuan untuk mengembangkan potensi siswa sehingga nantinya akan berdampak pada pencapaian prestasi siswa. Pelaksanaan pembinaan olahraga renang dibagi menjadi dua tempat, yaitu di sekolah dan di klub. Berikut diperjelas pada gambar 2.

\section{Gambar 2. Pelaksanaan Pembinaan Olahraga Renang}

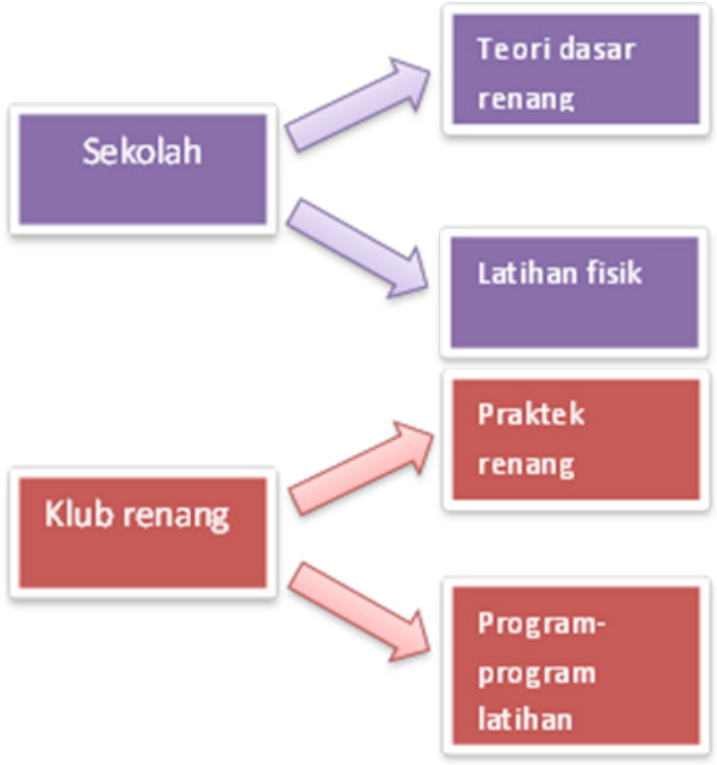

Gambar 3. Hambatan Pelaksanaan Pelaksanaan Olahraga Renang

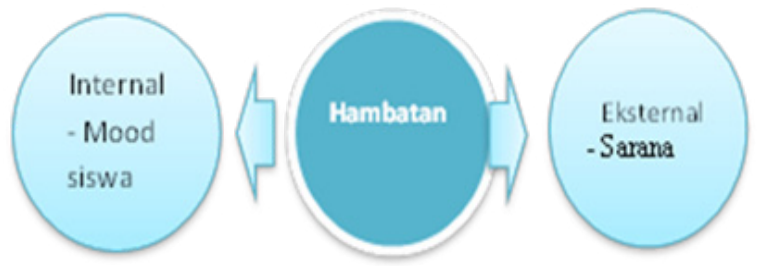

Pelaksanaan pembinaan olahraga renang di sekolah dilaksanakan setiap hari Jumat pada saat jam pelajaran olahraga. Siswa hanya diberi materi tentang teori-teori dasar olahraga renang dan juga diberikan latihan fisik terutama ketika menjelang perlombaan untuk menjaga kondisi fisik siswa. Di samping itu, pihak sekolah memberitahukan kepada orangtua terutama ketika mendekati perlombaan untuk menambah program-program latihan yang dilaksanakan di klub renang dengan tujuan agar siswa lebih siap dalam menghadapi perlombaan, sedangkan untuk praktek renang yaitu penerapan teori-teori dasar yang sebelumnya telah diajarkan sekolah dilakukan di klub renang. Selain itu siswa juga diberikan programprogram latihan, misalnya teknik renang, sprint renang, latihan start dan daya tahan.
Menurut hasil wawancara, observasi, dan studi dokumentasi yang telah dilakukan, ada beberapa hambatan pelaksanaan pembinaan olahraga renang di SMPLB Negeri Malang. Hambatan tersebut dapat digambarkan dalam gambar 3.

Hambatan dalam pelaksanaan pembinaan olahraga renang terbagi menjadi dua yaitu hambatan internal dan eksternal. Untuk hambatan internal yang terkait dengan mood siswa, yang akan mempengaruhi proses pelaksanaan pembinaan olahraga renang dan perlombaan renang. Hal tersebut pernah terjadi pada saat perlombaan khususnya bagi siswa yang tunagrahita down syndrome yang tiba-tiba tidak mood untuk mengikuti perlombaan begitupun pada saat latihan.

Untuk hambatan eksternal terkait sarana adalah sekolah belum memiliki kolam renang sendiri. Hal tersebut disebabkan oleh keterbatasan dana yang dimiliki sekolah serta tidak tersedianya lahan kosong untuk membangun kolam renang. Upaya yang dilakukan untuk mengatasi hambatan pembinaan olahraga renang di SMPLB Negeri Malang dapat digambarkan dalam diagram pada Gambar 4.

\section{Gambar 4. Upaya Mengatasi Hambatan Pembinaan Olahraga Renang}

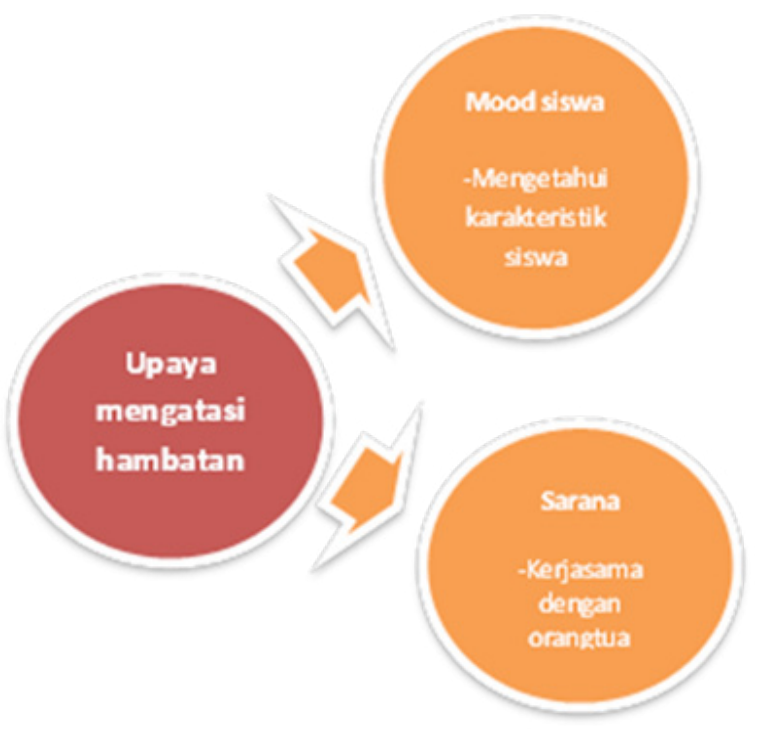

Upaya yang dilakukan untuk mengatasi hambatan yang terkait dengan mood siswa dapat diatasi dengan mengetahui lebih dalam karakteristik siswa. Dalam hal ini guru, orangtua, serta pelatih harus saling berkomunikasi tentang hal-hal yang berkaitan dengan siswa, misalnya apa yang disukai siswa, apa yang tidak disukai siswa dan hal-hal lain yang dapat mengembalikan mood siswa.

Selanjutnya untuk hambatan terkait dengan sarana yaitu melakukan kerjasama dengan orangtua siswa sehingga pelaksanaan pembinaan olahraga renang dapat berjalan dengan lancar. Kerjasama yang 
dilakukan adalah menjalin komunikasi yang baik terkait perkembangan bakat siswa.

\section{Pembahasan}

\section{Program Pembinaan Olahraga Renang}

Sebelum melakukan pembinaan olahraga renang, sekolah terlebih dahulu melakukan asessmen untuk mengetahui bakat dan minat siswa. Hal tersebut sesuai pernyataan Purnomo dan Haryana (2017:51) asesmen adalah suatu proses yang sistematis untuk pengumpulan data seorang anak sehingga dapat diketahui kemampuan dan kesulitan yang dihadapinya. Hal itu dilakukan agar siswa yang memiliki potensi dapat dikembangkan secara maksimal. Asessmen dilakukan pada saat awal siswa masuk di sekolah serta dilakukan asessmen lanjutan di setiap tahunnya. Dalam hal ini semua guru SMPLB Negeri Malang terlibat untuk melakukan asessmen. Setelah melakukan asessmen pihak sekolah melakukan komunikasi kepada orangtua dengan memberitahu bahwa siswa tersebut mempunyai bakat dalam olahraga renang. Pemberitahuan kepada orangtua dilakukan karena pihak sekolah merasa belum mampu untuk menangani pembinaan olahraga renang secara mandiri. Kerjasama yang dilakukan adalah mendaftarkan siswa untuk mengikuti klub renang. Setelah siswa didaftarkan dalam suatu klub renang, selanjutnya siswa akan mendapatkan programprogram latihan renang.

Program latihan renang yang didapatkan siswa di klub renang antara lain sebagai berikut: daya tahan, latihan sprint, dan teknik/gaya dalam berenang. Ada empat teknik/gaya yang diajarkan oleh klub renang, antara lain gaya dada, gaya kupu-kupu, gaya punggung, dan gaya bebas. Hal tersebut sesuai dengan teori yang dikemukakan Haller (2007:16) secara umum terdapat empat macam gaya dalam olahraga renang, yaitu gaya dada (breast stroke), gaya bebas (the crawl stroke), gaya kupu-kupu (butterfly stroke), dan gaya punggung (back crawl).

\section{Pelaksanaan Pembinaan Olahraga renang}

Pelaksanaan pembinaan olahraga renang di SMPLB Negeri Malang dilakukan sejak awal siswa masuk di sekolah. Pembinaan olahraga renang terbagi menjadi dua tempat, yaitu di sekolah dan di klub renang. Untuk di sekolah biasanya dilakukan pada saat mata pelajaran olahraga serta pada saat menjelang perlombaan, sekolah memberikan teori-teori dasar renang dan melakukan latihan fisik untuk menjaga kondisi fisik siswa. Kemudian untuk pelaksanaan pembinaan di klub dilakukan praktek renang dan pemberian program-program renang. Sarana dan prasarana pembinaan olahraga renang seluruhnya diserahkan kepada klub renang dikarenakan sekolah masih belum memiliki sarana dan prasarana yang lengkap untuk olahraga renang. Sarana tersebut meliputi baju renang, topi renang, dan kacamata renang. Hal tersebut selaras dengan pernyataan Hastuti (2009:24) bahwa perlengkapan renang yang digunakan selama beraktivitas di air adalah baju renang, topi renang, kacamata renang dan penjepit hidung (tambahan).

Pembinan olahraga renang untuk siswa berkebutuhan khusus dilaksanakan bersama dengan anak reguler. Terkait materi, tujuan dan evaluasi semua disamakan dengan anak reguler yang membedakan adalah pada prosesnya misalnya cara penyampaian materi. Cara penyampaian untuk siswa berkebutuhan khusus yaitu dengan menggunakan bahasa yang sederhana dan mudah dimengerti siswa serta dilakukan secara berulang-ulang.

Untuk mengukur keberhasilan pembinaan olahraga renang, sekolah selalu mengikutsertakan siswa untuk mengikuti lomba atau event-event atau perlombaan renang. Hal itu berguna sebagai tolak ukur sejauh mana siswa dapat mengembangkan potensi yang ada dalam dirinya.

\section{Hambatan Pembinaan Olahraga Renang}

Hambatan dalam pembinaan olahraga renang di SMPLB Negeri Malang ada dua, (1) tidak adanya sarana utama yaitu kolam renang di lingkungan sekolah. Kolam renang merupakan suatu hal penting yang harus ada dalam olahraga renang. Keterbatasan dana dan lahan kosong menjadi penyebab sekolah belum dapat membangun kolam renang sendiri. Di samping itu sekolah juga mewaspadai adanya respon negatif dari siswa (anak berkebutuhan khusus) yang lain misalnya dalam kasus tertentu ada siswa yang memiliki ketakutan yang berlebihan terhadap air sehingga nantinya akan mengganggu proses pembelajaran di sekolah.

Sedangkan hambatan yang kedua (2) siswa tunagrahita dalam pembinaan olahraga renang memiliki sedikit permasalahan atau hambatan yaitu mood siswa serta dalam penyampaian intruksi atau materi pelatih harus mengulang-ulang beberapa kali. Hal ini dibuktikan dengan pernyataan Somantri (2012) tunagrahita adalah seseorang yang mempunyai kemampuan intelektual di bawah rata-rata dan ditandai oleh ketidakcakapan dalam interaksi sosial serta keterbatasan intelegensi yang mengakibatkan dirinya sukar untuk mengikuti program pendidikan klasikal. Tunagrahita memiliki tingkat emosi yang masih labih. Hal itu membuat siswa tunagrahita sering mengalami perubahan mood yang cukup cepat.

\section{Upaya Mengatasi Hambatan Pembinaan Olahraga Renang}

Upaya mengatasi hambatan pembinaan olahraga renang terkait mood siswa yaitu dengan mengenali lebih dalam karakteristik siswa. Dalam hal ini baik pelatih, orangtua, maupun sekolah saling memberi masukan untuk pelaksanaan pembinaan olahraga 
renang misalnya hal-hal yang disukai siswa maupun hal-hal yang tidak disukai siswa. Salah satu saran dari orangtua kepada pelatih ketika siswa dalam kondisi tidak mood adalah dengan tidak memaksakan siswa untuk mengikuti program latihan tetapi lebih kepada memberikan hal-hal yang disukai oleh siswa terlebih dahulu baru kemudian secara perlahan mengajak siswa mengikuti program latihan renang.

Selanjutnya untuk upaya mengatasi hambatan terkait dengan tidak adanya sarana utama dalam olahraga renang adalah menjalin kerjasama dengan orangtua siswa. Kerjasama tersebut dilkukan dengan mendaftarkan siswa ke klub renang yang sesuai denan kebutuhan siswa. Kerjasama yang dilakukan tidak sampai disitu tetapi terus berlanjut selama proses pembinaan olahraga renang berlangsung dimana pihak sekolah dan orangtua saling berkomunikasi guna memantau sejauh mana perkembangan bakat siswa.

\section{KESIMPULAN DAN SARAN}

\section{Kesimpulan}

Berdasarkan pada fokus penelitian, paparan dan temuan data serta pembahasan maka dapat disimpulkan sebagai berikut: (1) Program Pembinaan Olahraga Renang di SMPLB Negeri Malang dirancang sekolah melalui asessmen, sekolah memberitahukan kepada orangtua untuk mendaftarkan siswa mengikuti klub renang dan siswa diserahkan di klub renang; (2) Pelaksanaan pembinaan olahraga renang di SMPLB Negeri Malang dibagi menjadi dua tempat, yaitu di sekolah dan di klub renang; (3) Hambatan pembinaan olahraga renang ada dua, yaitu (a) tidak adanya sarana utama olahraga renang, (b) mood siswa yang sering berubah; serta (4) Upaya mengatasi hambatan pembinaan olahraga renang di SMPLB Negeri Malang yaitu dengan kerjasama dengan orangtua siswa, dan mengenali lebih dalam karakteristik siswa.

\section{Saran}

Berdasarkan hasil temuan peneliti, agar pembinaan olahraga renang dapat berjalan lebih baik ke depannya, maka peneliti memiliki beberapa saran antara lain: (1) Bagi sekolah, diharapkan sekolah tetap melakukan penjaringan bakat dan minat yang nantinya dapat menghasilkan bibit-bibit unggul yang baru dalam olahraga renang; (2) Bagi kepala sekolah, hendaknya kepala sekolah dapat mengambil keputusan bijak dalam memilih salah seorang guru sebagai penanggungjawab olahraga renang; (3) Bagi pelatih, disarankan untuk mempelajari lebih dalam tentang karakteristik dan kebutuhan siswa berkebutuhan khusus; (4) Bagi guru, diharapkan guru dapat menggali lebih dalam lagi potensi-potensi yang ada pada seluruh siswa, karena peneliti merasa masih banyak potensi tersembunyi yang ada dalam diri siswa; dan (5) bagi peneliti selanjutnya, peniliti selanjutnya diharapkan dapat mengembangkan penelitian ini dalam ruang lingkup yang lain, seperti proses penjaringan awal atau tindak lanjut terkait pembinaan olahraga renang.

\section{DAFTAR RUJUKAN}

Efendi, M. (2008). Pengantar Psikopedagogik Anak Berkelainan. Jakarta: PT Bumi Aksara

Fatkhurohman, A. (2005). Upaya Kepala Sekolah dalam Meningkatkan Prestasi Siswa di MI Ma'arif Glagahombo, Sucen, Salam, Magelang. Skripsi. Fakultas Tarbiyah. UIN Sunan Kalijaga Yogyakarta, digilib.uin-suka.ac.id/2372/1/ BAB $\% 20 I \% 2 C \% 20 \mathrm{~V} \% 2 \mathrm{C} \% 20 \mathrm{DAFTAR} \% 20$ PUSTAKA.pdf

Haller, D. (2007). Belajar Berenang. Bandung: Pionir Jaya

Hastuti, P. (2009). Buku Panduan Cabang Olahraga Renang. Jakarta: Pengurus Pusat Special Olympic Indonesia

Peraturan Menteri Pendidikan dan Kebudayaan Republik Indonesia Nomor 81A Tahun 2013 Tentang Implementasi Kurikulum

Pradipta, R. F., \& Andajani, S. J. (2017). Motion Development Program for Parents of Child with Cerebral Palsy. Jurnal Penelitian dan Pengembangan Pendidikan Luar Biasa, 4(2).

Siregar, A.E.P., (2014). Pelaksanaan Pelatihan Renang Anak Autisme di Kolam Renang Selayang Medan. Skripsi. Fakultas Ilmu Keolahragaan. Universitas Negeri Medan. http://digilib.unimed.ac.id/9219/

Sismadiyanto \& Susanto, E. (2008). Dasar Gerak Renang. Yogyakarta: Fakultas Ilmu Keolahragaan

Somantri, S. (2006). Psikologi Anak Luar Biasa. Bandung: PT Refika Aditama

Sugiyono. (2008). Metode Penelitian Pendidikan. Bandung: Alfabeta

Utomo. (2016). Pendidikan Jasmani Adaptif bagi Anak Berkebutuhan Khusus Berwawasan Kebangsaan. Prosiding Seminar Internasional Pendidikan Berbasis Nilai-Nilai Kebangsaan., http://eprints. ulm.ac.id/1480/ 